\title{
KORELASI KEPEMIMPINAN KEPALA TAMAN KANAK-KANAK TERHADAP KINERJA KOMPETENSI PEDAGOGIK DAN KOMPETENSI PROFESIONAL GURU
}

\author{
Romlah $^{1 *}$ Untung Nopriansyah ${ }^{2}$, Sigit Purnama ${ }^{3}$ \\ ${ }^{1}$ Universitas Islam Negeri Raden Intan Lampung \\ *Email: romlah@radenintan.ac.id
}

\begin{abstract}
Abstrak
The types of research applied in this research was descriptive quantitative. It is a research methodology which established on positivism philosophy. This research was conducted in Kindergarten at Bandar Lampung sub-district. The purpose of this research was to know the interrelationship and correlation between the head of kindergarten leadership towards professionalism and pedagogical competence of teachers. Research analysis used was correlational analysis. The results of the analysis were (1). There was a correlation between the head of kindergarten leadership towards professionalism and pedagogical competence of teachers in Kedaton. It was shown by the coefficient of correlation value which was 0,37 , with the $t_{\text {measured }}$ test value 1,69 bigger than $t_{\text {table }}$ with the significant of $5 \%$ that was $-1,73$. (2). There was a correlation between professionalism of kindergarten teacher in Kedaton sub-district with the coefficient of correlation value 0,18 , and $t_{\text {measured }}$ test value 0,76 bigger than $t_{\text {table }}$ with the significant of $5 \%$ that was $-1,73$.
\end{abstract}

Kata Kunci: Correlation, leadership, Performance of competences

\section{Abstrak}

Jenis Penelitian yang digunakan dalam penelitian ini adalah deskriptif kuantitatif. Ini adalah metodologi penelitian yang didirikan pada filsafat positivisme. Penelitian ini dilakukan di Taman Kanak-kanak di kecamatan Bandar Lampung. Tujuan dari penelitian ini adalah untuk mengetahui hunungan timbal balik dan korelasi antara kepala kepemimpinan TK terhadap profesionalisme dan kompetensi pedagogik guru. Analisis penelitian ini yang digunakan adalah analisis korelasional. Hasil analisis adalah (1). Ada hubungan antara kepala kepemimpinan TK terhadap profesionalisme dan kompetensi pedagogik guru di kedaton. Hal ini ditunjukkan oleh nilai koefisien korelasi yaitu 0,37, dengan nilai tes t_measured 1,69 lebih besar dari t_(tabel) dengan signifikan 5\% yaitu -1,73. (2) ada hubungan antara profesionalisme guru TK di Kecamatan Kedaton dengan nilai koefisien korelasi 0,18, dan nilai tes terukur 0,76 lebih besar dari t_ (tabel) dengan signifikansi 5\% yaitu 1,73

Kata Kunci: Korelasi, Kepemimpinan, Kinerja dan kompetensi

\section{PENDAHULUAN}

Profesionalitas seorang guru sebagai pengajar sering kali menjadi sorotan oleh banyak orang. Karna profesionalitas seorang guru diperlukan, mengingat guru merupakan ujung tombak dari kegiatan pendidikan dan eksekutor pembelajaran dalam kelas. Guru sebagai Figure yang senantiasa menjadi sorotan strategis ketika berbicara 


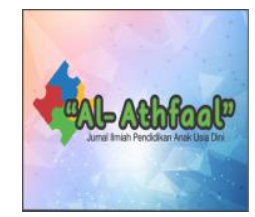

masalah kependidikan. Guru memegang peranan utama dalam pembangunan kependidikan, khususnya yang dijalankan secara formal di kolah. Selain itu guru adalah sosok yang menjadi uswah hasanah(panutan) yang mampu mengarahkan, mengubah perilaku dan karakter anak kearah yang lebih baik. Maka guru sangat menentukan keberhasilan anak yang kaitannya dengan proses pembelajaran. Sehingga tuntutan orang tua kepada guru yang selalu menginginkan anaknya memperoleh pembelajaran yang baik untuk anak mereka merupakan hal yang wajib dipenuhi oleh guru dan juga instansi yang terkait.

Guru saat penyampai informasi perlu memberikan latihan untuk memeriksa pemahaman anak dengan mengajukan pertanyaan untuk materi baru sebagai acuan dasar mengetahui pencapaian anak di dalam kelas. Hal ini yang membuat guru dituntut untuk profesional dalam mengajar. Seorang guru bisa dikatakan professional, bila didalam dirinya melekat sikap dedikasi yang tinggi terhadap tugasnya, sikap komitmen terhadap mutu proses dan hasil kerja, serta sikap continous improvement, yakni selalu berusaha memperbaiki dan memperbaharui metode pengajaran sesuai dengan kurikulum yang diberlakukan, yang dilandasi oleh kesadaran yang tinggi bahwa tugas mendidik adalah tugas menyiapkan generasi penerus bangsa masa yang akan datang.

Kompetensi pedagogik yang baik pun harus dimiliki seorang guru agar dapat memberikan pembelajaran dan pengajaran yang baik. Kompetensi pedagogik dan kompetensi profesional masing-masing guru tentunya berbeda. Hal-hal yang dapat mempengaruhi kompetensi pedagogik guru dan kompetensi profesional guru banyak sekali, mulai dari faktor internal maupun faktor eksternal. Faktor internal biasanya menjadi bawaan bagi masing-masing guru seperti minat dan bakat(Suharyat, 2009; Sunadi, 2013) (Fatthurrohman 2012). Objek minat guru dalam segi kegiatan adalah melihat reaksi guru mengembangkan suatu pembelajaran yang disukai atau tidak mereka sukai terhadap pembelajaran yang dilakukan. Selain minat seorang guru juga harus memiliki bakat mengajar. Jika guru sejak dini sudah memiliki bakat maka guru akan menunjukan kepiawaian dan professionalitas.

Seorang guru yang memiliki bakat mendidik akan lebih cepat membimbing dan mengarahkan anak serta cepat menguasi kondisi dan situasi dalam mengajar. Salah satu faktor yang mungkin dapat mempengaruhi kompetensi profesionalisme guru dan kompetensi pedagogik guru adalah pemimpin dari sekolah, yakni kepala sekolah. 


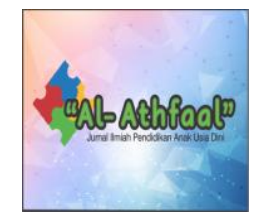

Menurut Engkay Karweti, mengatakan kemampuan manajerial kepala sekolah berpengaruh positif dan signifikan terhadap kinerja guru (Karweti, 2010; Setiyati, 2014; Werang, 2014) . Kemampuan manajerial kepala sekolah artinya dapat mempengaruhi kompetensi guru. Menurut Sri Setiyati mengatakan terdapat pengaruh yang positif dan signifikan antara kepemimpinan kepala sekolah terhadap kinerja guru. (Setiyati, 2014)

Namun, faktor eksternal pun banyak mempengaruhi kompetensi guru. Menurut Nurhayati Kompetensi profesionalisme dan kinerja guru dipengaruhi oleh faktor-faktor yang bersumber pada faktor input, proses, dan output. (Na'im, 2018; Nurhayati, 2016; Wahyuni, Komarudin, \& Anggoro, 2019). Faktor eksternal berkaitan erat dengan sarana dan prasarana. Tidak dipungkiri bahwa dalam pelaksanaan proses pembelajaran, keberadaan sarana dan prasana memberikan dampak yang besar bagi hasil pembelajaran. Pada dasarnya dalam sebuah instansi sarana dan prasana yang lengkap dan modern akan menarik perhatian anak dan memudahkan guru dalam proses pembelajaran yang berlangsung. (Akbar \& Komarudin, 2018)

Peranan pemimpin juga sangat menentukan pendidikan yang dilaksanakan di sekolah karena sekolah berfungsi untuk meneruskan nilai-nilai luhur bangsa kepada generasi muda serta sebagai tempat berlangsungnya proses pembelajaran. Terjadinya Proses Belajar Mengajar dan meneruskan nilai-nilai luhur yang efektif perlu adanya kerja sama yang baik antara guru dan anak, orang tua dan masyarakat disekitarnya.

Berdasarkan penelitian-penelitian terdahulu yang telah dilakukan maka peneliti ingin meneliti dan melihat apakah terdapat korelasi kepemimpinan kepala Taman Kanak-Kanak terhadap kompetensi profesionalisme dan kompetensi pedagogik guru Taman Kanak-Kanak di kecamatan Kedaton Bandar Lampung. Tujuan dari penelitian ini ingin mengetahui hubungan kepemimpinan kepala Taman Kanak-Kanak terhadap masing-masing kompetensi profesionalisme dan kompetensi pedagogik, serta ingin melihat apakah terdapat korelasi dari kepemimpinan terhadap dua kompetensi sekaligus.

\section{PEMBAHASAN}

Kepemimpinan dalam pendidikan merupakan salah satu faktor yang sangat menuntukan keberhasilan visi dan misi sekolah. Penggerak kepemimpinan yang dimaksud merupakan Kepala Sekolah/Madrasah dengan bantuan pendidik, lingkungan, dan juga masyarakat. Kualitas kepemimpinan berpengaruh besar terhadap kesuksesan 


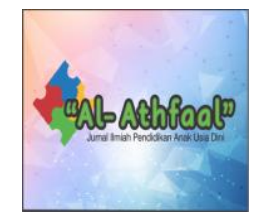

lembaga/organisasi sebagaimana banyak penelitian di berbeagai negera maju menyatakan bahwa kepimimpian merupakan variable yang berkontribusi sebesar $40 \%$ dalam pencapaian sekolah, sementara $60 \%$ ditentukan dengan variable-variable lain. Sedangkan dalam temuan lain, kepemimpinan hanya berpengaruh kecil dipresentasikan rata-rata sebesar 10\% dan 90\% sisanya dimiliki variable lain. (Imam Machali, 2012; Pramelasari \& PRASTIWI, 2010; Winoto \& Falikhatun, 2015)

Menurut Hadari Nawawi kepemimpinan diartikan sebagai kemampuan menggerakkan, memberikan motivasi dan mempengaruhi orang-orang agar bersedia melakukan tindakan-tindakan yang terarah pada pencapaian tujuan melalui keberanian mengambil keputusan tentang kegiatan yang dilakukan(Hadari Nawawi, 1988; Nurlia, 2017; Syamsul, 2017). Pakar lain berpendapat bahwa, kepemimpinan adalah usaha yang dilakukan untuk mempengaruhi anggota kelompok agar mereka dengan suka rela menyumbangkan kemampuannya secara maksimal demi pencapaian tujuan kelompok yang telah ditetapkan(Mariam, 2009; Marimin, 2011; Suharsimi Arikunto, t.t.). Disimpulkan bahwa kepemimpinan adalah usaha kolektif dalam bentuk berpikir,menggerakan, memberikan motivasi, mempengaruhi, menyumbangkan pikiran dan kemampuan secara suka rela demi tercapainya tujuan yang telah dirumuskan.

Kepemimpinan kaitannya dalam Lembaga/Organisasi merupakan hak seorang Kepala Sekolah. Konsep-konsep keberhasilan dalam sekolah ditentukan oleh bagaimana Kepala Sekolah memimpin institusi. Prestasi suatu lembaga mempunyai hubungan yang signifikan dari profesionalitas dan karakteristik pemimpinnya.(Kasidi, 2016; Marno dan Triyo Supriyatno, 2008; Syafar, 2017)

Jadi, Kepemimpinan dalam pendidikan adalah faktor yang sangat menuntukan keberhasilan visi dan misi sekolah. Pemimpin memberikan pengaruh terhadap orangorang yang mengikuti untuk mencapai tujuan. Selain Kepala sekolah, pengaruh guru juga penting dalam dunia kependidikan. Guru menjadi pemimpin di dalam kelas pun menjadi penentu proses pembelajaran. Kinerja guru merupakan sebuah unjuk kerja yang dilakukan oleh guru dalam melaksanakan tugasnya. Di undang- undang menyatakan bahwa kompetensi guru dapat berupa kinerja guru yang mampu dilihat dari aspek kemampuan dasar (Hasanah, 2010; Ismail, 2010; Murwati, 2013). Menurut UUD 14/2005 Pasal 8 dan Permen Diknas No. 13 Tahun 2007 kompetensi pedagogik dan 


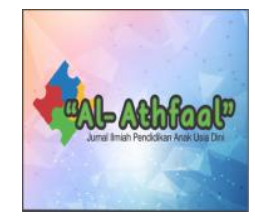

kompetensi professional merupakan bagian dari kompetensi yang harus dimiliki seorang pengajar.

Kompetensi Pedagogik merupakan suatu kemampuan seseorang dalam mengelola pembelajaran anak yang meliputi pemahaman terhadap peserta didik, perancangan dan pelaksanaan pembelajaran, evaluasi dan hasil belajar, dan pengembangan anak untuk mengaktualisasikan berbagai potensi yang dimilikinya. Guru harus mampu memahami karakteristik, kebutuhan dan perkembangan anak didik, menguasai dasar-dasar pendidikan, menguasai prinsip dan pendekatan dalam belajar, menguasai dasar-dasar bimbingan.

Kompetensi lain yang harus dimiliki seorang guru adalah kompetensi professional. Kompetensi profesional adalah kemampuan penguasaan materi pembelajaran secara luas dan mendalam yang memungkinkannya membimbing anak memenuhi standar kompetensi yang ditetapkan dalam Standar Nasional Pendidikan. Kompetensi ini merupakan kompetensi yang sangat penting, sebab langsung berhubungan dengan kinerja yang ditampilkan (Hasan, 2017; Poerwanti \& Widodo, 2005). Kompetensi professional dapat diartikan dengan kemampuan, wewenang. Seperti yang dikatakan oleh Ngainun Naim bahwa "kata kompetensi secara harfiyah dapat diartikan sebagai kemampuan. Kompetensi yang memadai seseorang khususnya guru dapat melaksanakan tugasnya dengan baik. (Darimi, 2015; Karweti, 2010; Muhson, 2004; Naim, 2009).

Kompetensi profesional guru adalah seperangkat kemampuan yang harus dimiliki oleh seorang guru agar ia dapat melaksanakan tugas mengajar dengan berhasil (Baharun, 2018; Gulo, 2008; Hamzah B. Uno, 2007; Ismail, 2010). Kompetensi profesional yang perlu dimiliki oleh setiap guru antara lain: kemampuan untuk mengembangkan kepribadian pribadi peserta didik, khususnya kemampuan intelektualnya karena seorang guru tidak hanya menjabat sebagai guru, melainkan untuk mengeluarkan kemampuannya sebagai pendidik untuk peningkatan akademis dan non akademis peserta didik.

Guru yang profesional yaitu dengan tugas utama mendidik, mengajar, membimbing, mengarahkan, melatih, menilai, dan mengevaluasi anak pada pendidikan anak usia dini jalur pendidikan formal, pendidikan dasar, dan pendidikan menengah. 


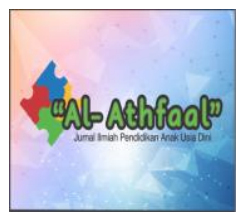

Disimpulkan bahwasanya dalam mencapai keberhasilan sebuah instansi, peran kepemimpinan seorang kepala sekolah sangat berpengeruh dalam menggerakan perangkta sekolah seperti guru. Hal tersebut berkaitan langsung pada kompetensi pedagogik guru dan profesionalnya.

\section{METODE PENELITIAN}

Jenis penelitian yang digunakan adalah penelitian deskristif kuantitatif (Nanang Martono, 2014). Penelitian kuantitatif adalah metode penelitian yang berlandaskan pada filsafat positivisme, digunakan untuk meneliti populasi atau sampel tertentu. Penelitian deskriptif dalam hal ini merupakan salah satu bentuk penelitian kuantitatif dan dikatakan sebagai penelitian kuantitatif yang paling dasar.

Populasi, Sampel, Sampling Populasi sebelum penelitian dilaksanankan, maka penulis terlebih dahulu menentukan populasi yang akan diteliti. "Populasi adalah wilayah generalisasi yang terdiri atas: objek/subyek yang mempunyai kualitas dan karakteristik tertentu yang ditetapkan oleh peneliti untuk dipelajari dan ditarik kesimpulan". Teknik pengambilan sampel pada umumnya dilakukan secara random, pengumpulan data menggunakan instrumen penelitian, analisis data bersifat kuantitatif/statistik dengan tujuan untuk menguji hipotesis yang telah ditetapkan (Sugiono, 2013). Teknik pengumpulan data yang digunakan wawancara, dokumentasi, dan angket.

Analisis kuantitatif yang digunakan dalam penelitian ini adalah analisis korelasi.Untuk melihat ada atau tidaknya hubungan antara Kepemimpinan Kepala Taman Kanak-Kanak $(x)$ dan Kemampuan pedagogik guru $\left(y_{1}\right)$ serta untuk melihat hubungan antara Kepemimpinan Kepala Taman Kanak-Kanak $(x)$ dan Kemampuan profesionalitas guru $\left(y_{2}\right)$. Analisis korelasi yang digunakan adalah analisis korelasi product moment. karena data yang digunakan merupakan data berskala likert. Adapun rumus korelasi yang digunakan adalah:

$$
r_{x, y}=\frac{n \sum_{i=1}^{n} x_{i} y_{1}\left(\sum_{i=1}^{n} x_{i}\right)\left(\sum_{i=1}^{n} y_{i}\right)}{\sqrt{\left[n \sum_{i=1}^{n} x_{i}{ }^{2}-\left(\sum_{i=1}^{n} x_{i}\right)^{2}\right]\left[n \sum_{i=1}^{n} y_{i}{ }^{2}-\left(\sum_{i=1}^{n} y_{i}\right)^{2}\right]}}
$$

Keterangan :

$r_{x, y} \quad:$ Korelasi antara variabel $x$ dan $y$ 


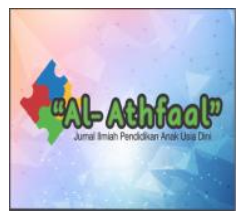

$n \quad$ : jumlah sampel

Berdasarkan hasil perhitungan koefisien korelasi product moment, selanjutnya dilakukan pengujian signifikansi melalui uji t dengan rumus :

$$
\begin{aligned}
t_{\text {hitung }} & =\frac{r_{X, Y} \sqrt{n-2}}{\sqrt{1-r_{X, Y}^{2}}} \\
t_{\text {tabel }} & =t_{(\alpha, n-2)}
\end{aligned}
$$

Hipotesis:

$H_{0} \quad$ : Tidak ada hubungan yang berarti antara variabel

$H_{1} \quad$ : Ada hubungan yang berarti antara Variabel

Bila $t_{\text {hitung }}>t_{\text {tabel }}$ maka tolak $H_{0}$, artinya ada hubungan yang berarti antara variabel.

\section{HASIL DAN PEMBAHASAN}

Data mengenai kepemimpinan kepala taman kanak-kanak diperoleh melalui intrumen angket yang disebar ke sekolah-sekolah TK seKecamatan Kedaton. Instrument angket sebelum diberikan ke populasi penelitian terlebih dahulu angket diujicobakan ke luar populasi untuk menguji validitas dan reliabilitas angket. Setelah diuji validitas dan reliabilitas angket kemudian digunakan untuk mengukur kepemimpinan kepala Taman Kanak-Kanak di TK pada Kecamatan Kedaton. Berdasarkan pengukuran tersebut diperoleh hasil yang terdapat pada Tabel 1 .

Tabel 1.Deskripsi Data Kepemimpinan Kepala TK (X)

\begin{tabular}{llllllll}
\hline Mean & Median & Modus & Minimum & Maksimum & Jangkauan & D & Ragam \\
\hline 9,41 & 0,94 & 5 & 75 & 97,50 & 22,5 & 7,27 & 52,86 \\
\hline
\end{tabular}

Mean (rata-rata) kepemimpinan kepala taman kanak-kanak di kecamatan Kedaton 89,41 dengan median 90,94 dan modusnya yaitu 95. Nilai kepemimpinan Kepala Taman Kanak-kanak sebesar 97,50 dan terendah 75, sehingga jangkauannya sebesar 22,5. Ukuran simpangan baku (Standar Deviasi/SD) sebesar 7,27. Keragaman data kepemimpinan Kepala Taman Kanak-kanak sebesar 52,86. Responden dalam 


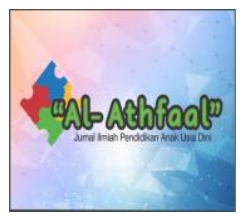

AL ATHFAAL: Jurnal IImiah Pendidikan Anak Uisa Dini

e-ISSN : $2622-5182$

Vol. 2 No. 1 (2019)

p-ISSN : 2622-5484

http://ejournal.radenintan.ac.id/index.php/al-athfaal

Juni 2019

penelitian ini sebanyak 20 orang guru Taman Kanak-kanak di kecamatan Kedaton. Dua guru yang menilai kepemimpinan kepala Taman Kanak-kanak masih rendah yaitu dengan nilai 75. Nilai kepemimpinan kepala taman kanak-kanak tertinggi 97,5 dinilai oleh tiga guru taman kanak-kanak di kecamatan Kedaton. Hal ini dapat dilihat jelas pada Gambar 1.

Gambar 4.1.Histogram Kepemimpinan Kepala TK



Deskripsi Data Kompentensi Pedagogik Guru $\left(X_{1}\right)$

Tabel 2.Deskripsi Data Kompentensi Pedagogik

\begin{tabular}{cccccccc}
\hline Mean & Median & Modus & Minimum & Maksimum & Jangkauan & D & Ragam \\
\hline 1,02 & 2,95 & 5,22 & 67 & 86,36 & 19,32 & 5,14 & 26,38 \\
\hline
\end{tabular}

Mean (rata-rata) kompetensi pedagogik guru di kecamatan Kedaton 81,02, mediannya tidak jauh berbeda yaitu 82,95 sedangkan modus untuk kompetensi pedagogik guru di kecamatan Kedaton yaitu 85,22. Nilai kompetensi pedagogik guru di kecamatan Kedaton tertinggi sebesar 86,36 dan terendah 67, sehingga jangkauannya sebesar 19,32. Ukuran simpangan baku (Standar Deviasi/SD) sebesar 5,14. Keragaman data kopetensi pedagogik guru di kecamatan kedaton sebesar 26,38. Responden dalam penelitian ini sebanyak 20 guru TK di kecamatan Tanjung Karang Pusat. Satu guru yang mendapat nilai kopetensi pedagogik guru terendah yaitu 67,05 dan tertinggi 85,23 dimiliki oleh lima orang guru TK di kecamatan Kedaton. Hal ini dapat dilihat jelas pada Gambar 2. 


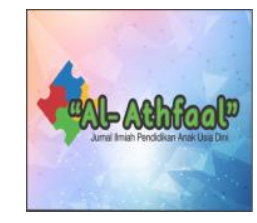

\section{Gambar 2.Histogram kopetensi pedagogik guru di kecamatan kedaton}

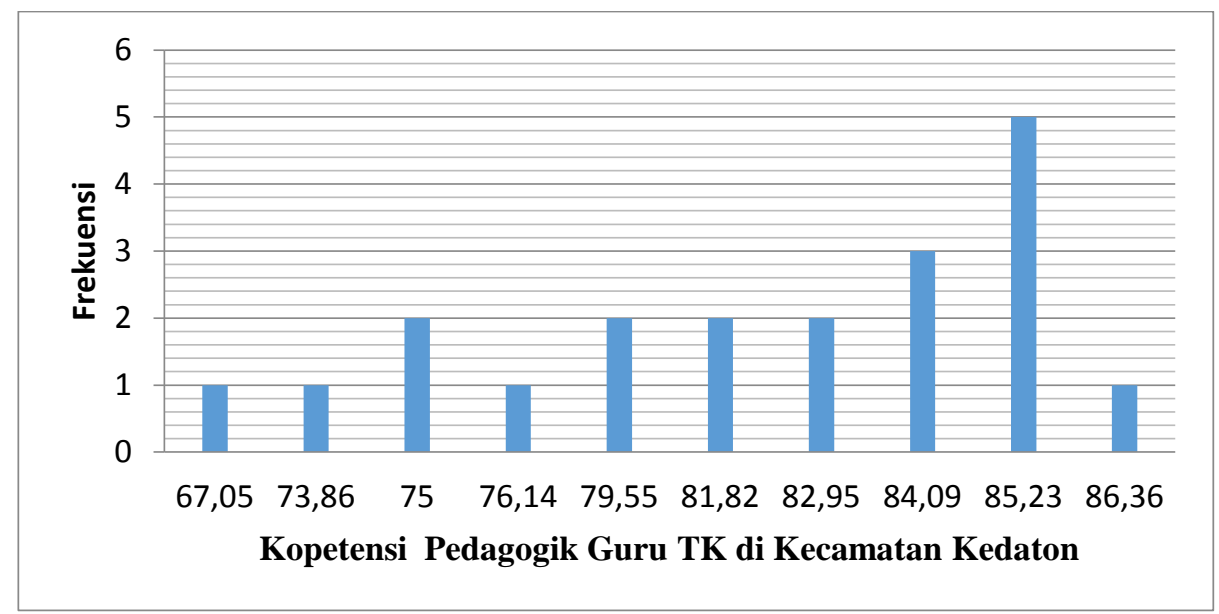

Tabel 3.Deskripsi Data Perkembangan Kreatifitas Anak Usia Dini

\begin{tabular}{llllllll}
\hline Mean & Median & Modus & Minimum & Maksimum & Jangkauan & D & Ragam \\
\hline 0,81 & 82,50 & 2,50 & 68,75 & 87,50 & 18,75 & 5,09 & 5,87 \\
\hline
\end{tabular}

Mean (rata-rata) kompetensi professional guru TK di kecamatan kedaton 80,81, mediannya tidak jauh berbeda yaitu 82,50 sedangkan modus untuk kompetensi professional guru TK di kecamatan kedaton yaitu 82,50. Nilai kompetensi professional guru TK di kecamatan kedaton tertinggi sebesar 87,50 dan terendah 68,75.Sehingga jangkauannya sebesar 18,75. Ukuran simpangan baku (Standar Deviasi/SD) sebesar 5,09. Keragaman data kompetensi professional guru TK di kecamatan kedaton sebesar 25,87. Responden dalam penelitian ini sebanyak 20 orang guru TK di kecamatan kedaton. Satu orang guru yang mendapat nilai kompetensi professional guru TK terendah yaitu 68,75 dan tertinggi 87,5 juga diperoleh oleh satu orang guru. Hal ini dapat dilihat jelas pada Gambar 3. 

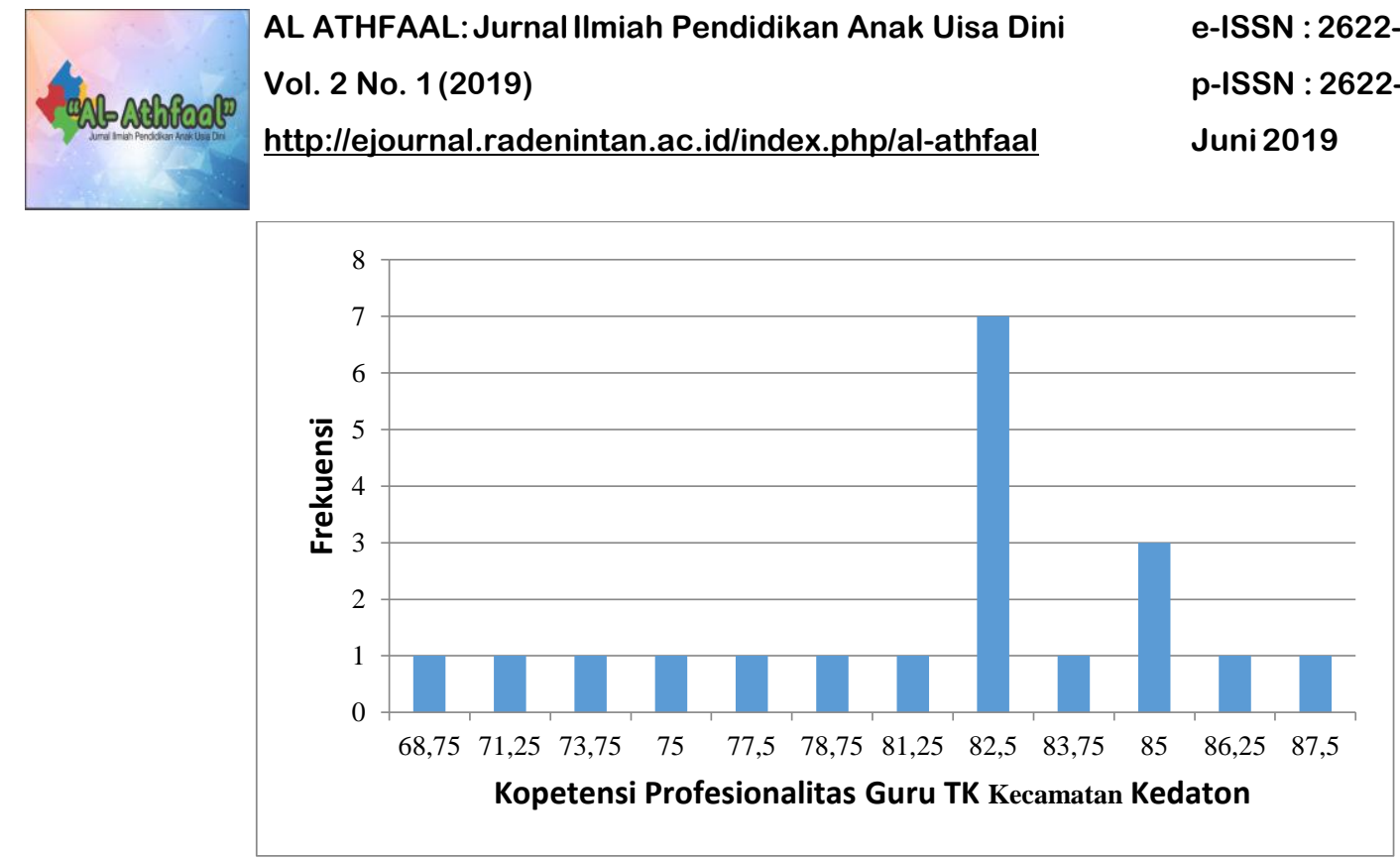

Gambar 3.Histogram Kompetensi Professional Guru TK

Hasil Analisis hubungan antara Kepemimpinan Kepala TK dengan Kopetensi Pedagogik Guru, serta hubungan antara Kepemimpinan Kepala TK dengan Kopetensi Profesional Guru dapat dilihat dalam Tabel 4.

Tabel 4.4. Analisis Hubungan Antar Variabel

\begin{tabular}{lcll}
\hline \multicolumn{1}{c}{ Analisis } & $\boldsymbol{r}$ & $\boldsymbol{t}_{\text {hitung }}$ & $\boldsymbol{t}_{\text {tabel }}$ \\
\hline $\begin{array}{l}\text { Hubungan Antara kepemimpinan } \\
\text { kepala Tk dengan Kopetensi Pedagogik }\end{array}$ & 0,37 & 1,69 & 1,73 \\
\hline $\begin{array}{l}\text { Hubungan Antara kepemimpinan } \\
\text { kepala Tk dengan Kopetensi }\end{array}$ & & & \\
Profesional & 0,18 & 0,76 & 1,73 \\
\hline
\end{tabular}

Berdasarkan Tabel 4 terlihat bahwa hasil analisis hubungan antara kepemimpinan kepala TK dengan kopetensi pedagogik guru di kecamatan kedaton memperoleh nilai koefisien korelasi sebesar 0,37, dengan nilai uji $t_{\text {hitung }}$ sebesar 1,69 yang lebih besar dari $t_{\text {tabel }}$ dengan taraf signifikansi 5\% sebesar $-1,73$. Berdasarkan hasil perhitungan tersebut maka dapat disimpulkan terdapat hubungan antara kepemimpinan kepala TK dengan kopetensi pedagogik guru.Nilai koefesien korelasi ( $\mathrm{r}$ ) =0,37 sehingga $R^{2}=0,37^{2}=0,1369$ artinya sebesar $13,69 \%$ keragaman kopetensi pedagogik guru dapat dijelaskan oleh kepemimpinan kepala TK dalam hubungan linier.

Selain itu hasil analisis hubungan antara kepemimpinan kepala TK dengan kopetensi profesional guru di kecamatan kedaton memperoleh nilai koefisien korelasi 


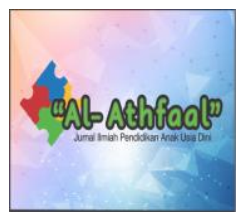

sebesar 0,18, dengan nilai uji $t_{\text {hitung }}$ sebesar 0,76 yang lebih besar dari $t_{\text {tabel }}$ dengan taraf signifikansi 5\% sebesar -1,73. Berdasarkan hasil perhitungan tersebut maka dapat disimpulkan terdapat hubungan antara kepemimpinan kepala TK dengan kopetensi profesional guru.Nilai koefesien korelasi $(r)=0,18$ sehingga $R^{2}=0,18^{2}=0,0324$ artinya sebesar 13,69\% keragaman kopetensi profesional guru dapat dijelaskan oleh kepemimpinan kepala TK dalam hubungan linier.

\section{KESIMPULAN}

Penelitian ini sebagaimana telah dijelaskan pada bab-bab sebelumnya terlihat bahwa variabel kepemimpinan kepala TK memiliki hubungan dengan kopetensi pedagogik guru dan kopetensi professional guru dengan dukungan temuan temuan sebagai berikut: (1). Terdapat Hubungan Antara Kepemimpinan Kepala TK dengan Kopetensi Pedagogik Guru TK di Kecamatan Kedaton. Ditunjukkan dengan nilai koefisien korelasi sebesar 0,37, dengan nilai uji $t_{\text {hitung }}$ sebesar 1,69 yang lebih besar dari $t_{\text {tabel }}$ dengan taraf signifikansi 5\% sebesar -1,73. (2). Terdapat Hubungan Antara Kepemimpinan Kepala TK dengan Kopetensi Profesional Guru TK di Kecamatan Kedaton. nilai koefisien korelasi sebesar 0,18 , dengan nilai uji $t_{\text {hitung }}$ sebesar 0,76 yang lebih besar dari $t_{\text {tabel }}$ dengan taraf signifikansi 5\% sebesar $-1,73$.

Bagi peneliti lain yang berminat melakukan penelitian yang sejenis disarankan tidak hanya diteliti secara parsial, namun coba lebih diteliti hingga tahapan analisis secara simultan apakah kepemimpinan kepala memiliki hubungan sekaligus untuk mempengaruhi kopetensi pedagogik guru dan kompetensi profesionalitas guru dalam mengajar secara bersamaan.

\section{DAFTAR PUSTAKA}

Akbar, R. R. A., \& Komarudin, K. (2018). Pengembangan Video Pembelajaran Matematika Berbantuan Media Sosial Instagram sebagai Alternatif Pembelajaran. Desimal: Jurnal Matematika, 1(2), 209-215.

Baharun, H. (2018). Peningkatan kompetensi guru melalui sistem kepemimpinan kepala madrasah. At-Tajdid: Jurnal Ilmu Tarbiyah, 6(1), 1-26.

Darimi, I. (2015). Peningkatan Kompetensi Pedagogik Guru PAI dalam Pembelajaran. Jurnal MUDARRISUNA: Media Kajian Pendidikan Agama Islam, 5(2), 309-324. 


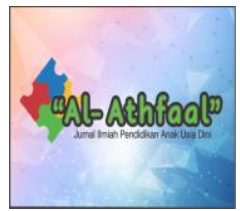

Gulo, W. (2008). Strategi Belajar Mengajar (Cover Baru). Grasindo.

Hadari Nawawi. (1988). Administrasi Pendidikan. Jakarta: Haji Masagung.

Hamzah B. Uno. (2007). Profesi Kependidikan Problema, Solusi dan Reformasi Pendidikan di Indonesia, (:, 2007), Jakarta: BumiAksara.

Hasan, M. (2017). Pengaruh Kompetensi Profesional Guru Terhadap Kinerja Guru Ekonomi Sekolah Menengah Atas Negeri Di Kabupaten Gowa. Economix, 5(2).

Hasanah, D. S. (2010). Pengaruh pendidikan Latihan (DIKLAT) Kepemimpinan Guru Dan Iklim Kerja terhadap Kinerja Guru Sekolah Dasar se Kecamatan Babakancikao Kabupaten Purwakarta. Jurnal Penelitian Pendidikan, 11(2), 85-96.

Imam Machali. (2012). Kepemimpinan Pendidikan dan Pembangunan Karakter. Yogyakarta: Pedagogia.

Ismail, M. I. (2010). Kinerja dan kompetensi guru dalam pembelajaran. Lentera Pendidikan: Jurnal Ilmu Tarbiyah dan Keguruan, 13(1), 44-63.

Karweti, E. (2010). Pengaruh kemampuan manajerial kepala sekolah dan faktor yang mempengaruhi motivasi kerja terhadap kinerja guru SLB di Kabupaten Subang. Jurnal penelitian pendidikan, 11(2), 77-89.

Kasidi, K. K. (2016). Hubungan antara Komitmen Kepemimpinan dan Budaya Organisasi dengan Kinerja Guru di SMP Negeri Sekecamatan Putri Hijau. Manajer Pendidikan, $10(3)$.

Mariam, R. (2009). Pengaruh Gaya Kepemimpinan dan Budaya Organisasi terhadap kinerja karyawan melalui kepuasan kerja karyawan sebagai variabel intervening studi pada Kantor Pusat PT. Asuransi Jasa Indonesia (Persero). program Pascasarjana Universitas Diponegoro.

Marimin, A. (2011). Pengaruh Gaya Kepemimpinan, Motivasi Kerja dan Budaya Organisasi terhadap Kinerja Karyawan pada Bank Muamalat Indonesia Cabang Surakarta. IAIN Surakarta.

Marno dan Triyo Supriyatno. (2008). Manajemen dan Kepemimpinan Pendidikan Islam. Bandung: Refika Aditama.

Muhson, A. (2004). Meningkatkan Profesionalisme Guru: Sebuah Harapan. Jurnal Ekonomi dan Pendidikan, 1(2).

Murwati, H. (2013). Pengaruh sertifikasi profesi guru terhadap motivasi kerja dan kinerja guru di smk negeri se-Surakarta. Jurnal Pendidikan Bisnis dan Ekonomi (BISE), 1(1), 1-10.

Naim, N. (2009). Menjadi guru inspiratif: Memberdayakan dan mengubah jalan hidup siswa. Pustaka pelajar.

Na'im, Z. (2018). Model Pendekatan Peningkatan Mutu Pendidikan Agama Islam. journal EVALUASI, 1(1), 100-118. 


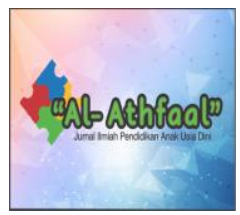

Nanang Martono. (2014). Metode Penelitian Kuantitatif Analisis Isi dan Analisis Data Sekunder. Jakarta: PT Rajagrafindo Persada.

Nurhayati, N. (2016). Upaya Guru Bahasa Arab dalam Meningkatkan Minat Belajar Bahasa Arab Peserta Didik pada MAN 2 Watampone. Universitas Islam Negeri Alauddin Makassar.

Nurlia, R. (2017). Pengaruh Gaya Kepemimpinan Terhadap Kinerja Karyawan Pada Pt. AlIjarah Indonesia Finance Lampung. UIN Raden Intan Lampung.

Poerwanti, E., \& Widodo, N. (2005). Perkembangan peserta didik. Universitas Muhammadiyah Malang.

Pramelasari, Y. M., \& PRASTIWI, A. (2010). Pengaruh intellectual capital terhadap nilai pasar dan kinerja keuangan perusahaan. Perpustakaan FE UNDIP.

Setiyati, S. (2014). Pengaruh kepemimpinan kepala sekolah, motivasi Kerja, dan budaya sekolah terhadap kinerja guru. Jurnal Pendidikan Teknologi dan Kejuruan, 22(2), 200206.

Sugiono. (2013). Metode Penulisan Kuantitatif, Kuatitatif dan $R \&$ D. Bandung: Alfabeta.

Suharsimi Arikunto. (t.t.). Organisasi dan Administrasi Pendidikan Teknologi dan Kejuruan. Jakarta: Rajawali Pers.

Suharyat, Y. (2009). Hubungan antara sikap, minat dan perilaku manusia. Jurnal Region, 1(3), $1-19$.

Sunadi, L. (2013). Pengaruh motivasi belajar dan pemanfaatan fasilitas belajar terhadap prestasi belajar siswa pada mata pelajaran ekonomi kelas XI IPS di SMA Muhammadiyah 2 Surabaya. Jurnal Pendidikan Ekonomi (JUPE), 1(3).

Syafar, D. (2017). Teori Kepemimpinan Dalam Lembaga Pendidikan Islam. Tadbir: Jurnal Manajemen Pendidikan Islam, 5(1), 147-155.

Syamsul, H. (2017). Penerapan Kepemimpinan Kepala Sekolah Dalam Meningkatkan Kinerja Guru Pada Jenjang Sekolah Menengah Pertama (SMP). Idaarah: Jurnal Manajemen Pendidikan, 1(2).

Wahyuni, T., Komarudin, K., \& Anggoro, B. S. (2019). Pemahaman Konsep Matematis Melalui Model Wee Dengan Strategi Qsh Ditinjau Dari Self Regulation. AKSIOMA: Jurnal Program Studi Pendidikan Matematika, 8(1).

Werang, B. R. (2014). Pengaruh kepemimpinan transformasional kepala sekolah, moral kerja guru, dan kepuasan kerja terhadap kinerja guru SDN di Kota Merauke. Jurnal Cakrawala Pendidikan, 33(1).

Winoto, A. H., \& Falikhatun, F. (2015). Indikasi penyalahgunaan discretionary fund dalam Anggaran Pendapatan dan Belanja Daerah menjelang Pemilukada 2015. Jurnal Akuntansi dan Keuangan Indonesia, 12(1), 75-91. 
e-ISSN : 2622-5182

Vol. 2 No. 1 (2019)

p-ISSN : 2622-5484

http://ejournal.radenintan.ac.id/index.php/al-athfaal

Juni 2019 